This is an Accepted Manuscript of an article published by Taylor \& Francis Group in Journal of Small Business \& Entrepreneurship on 29 Jan 2019, available online:

http://www.tandfonline.com/10.1080/08276331.2018.1541681.

\title{
Collaboration in entrepreneurship education: challenges, opportunities and innovations
}

Entrepreneurship, through the contribution of entrepreneurial individuals and businesses to the economy and wider society, has gained prominence for those seeking 'productivity growth [and to] foster quality job creation, strengthen trade and investment, and reduce inequalities' (OECD, 2018). As the perceived value of entrepreneurship has risen and it has become viewed as a solution to economic and social problems. attention has turned to expanding entrepreneurship education (Katz, 2003; Kuratko, 2005). If societies need more entrepreneurial citizens, how might universities educate these citizens and on what terms would we judge their success? This raises fundamental questions about what exactly it is that entrepreneurship education seeks to achieve (Duval-Couetil, 2013; Higgins, Refai and Keita, this issue) and how it might go about this. How does entrepreneurship education challenge traditional forms of classroom learning and does entrepreneurship education demand something new pedagogically, not only from the educators but for the role of the higher education institutions (HEIs) themselves?

At 'the crossroads of entrepreneurship and education' (Fayolle, 2013), there are several avenues for potential development and alternative routes forwards. Each route brings challenges, such as legitimacy and the balance between theory and practice, but also new opportunities and potential innovations (Katz, 2003). Central to making sense of this landscape are questions about what is distinctive about entrepreneurship education (Neck and Greene, 2011) and how it differs from other forms of business education. For example, what might entrepreneurship education mean for students in terms of gaining practical experience, the types of skills required or the psychology or mindset involved and the ways 
in which these might be developed? This Special Issue focuses on the value of collaboration in answering these questions.

The benefits of collaboration can be seen in response to the potential incongruence between the (stereotyped and increasingly misrepresented) ivory tower teaching of academics and the hard-won, real-world experience of entrepreneurs. A response to this dilemma is to suggest the importance of the latter entering the classroom (Kuratko, 2005) and the former engaging more closely with entrepreneurial practice (Higgins, Refai and Keita, this issue). Nonetheless, such approaches produce implications throughout the institution and beyond; they necessitate new partners, new ways of learning and modes of assessment (Fayolle, Verzat and Wapshott, 2016; Solomon, Duffy and Tarabishy, 2002) if we are to move beyond guest speakers on traditionally taught modules to thinking about how academics and entrepreneurs might collaborate in the design and delivery of programmes.

Collaboration can also involve the interactions between different disciplines (Janssen and Bacq, 2010; McCarver, Jessup and Davis, 2010) as well as with other stakeholders, organisations and funding bodies (Maas and Jones, 2017; Pugh et al, 2016). The claimed centrality of entrepreneurship to the economy and society, tackling forms of disadvantage, engaging in social enterprise as well as more traditional profit-seeking ventures necessitates the broadening of entrepreneurship education beyond business schools (Duval-Couetil, 2013). This involves elements of entrepreneurship, and therefore potential collaboration, entering new areas of the academic curriculum. However, with this expansion into new disciplines and new forums comes attendant challenges in terms of issues of legitimacy, value and application that are likely to create significant challenges for future curriculum development (see e.g. Wyness and Jones, this issue). 
Beyond the classroom and the formal curriculum, the development of entrepreneurship education has also suggested alternative ways of thinking about the roles of HEls. This changing role is highlighted in several of the articles in this Special Issue in terms of the modern 'entrepreneurial university' as a response to HEls' 'third mission' through collaboration with industry and government (Philpott, Dooley, O'Reilly and Lupton, 2011). This reflects the increasingly complex interconnections and interdependencies between higher education, society and the economy (Jongbloed, Enders and Salerno, 2008). Culkin (2016), in a review of HEl activity supporting entrepreneurship, identifies how HEls can be a focus of financial resources and government action that relates to activities extending beyond the walls of the institution. In this type of role, HEls can also act as 'anchor institutions', embedded within and committed to particular regions and to regional development (Menzies, 2010; Nicolosi and Keeling, 2013). However, despite the potential for significant impacts, Pugh et al (2016) suggest that such broader roles for HEls, and in turn alternative forms of collaboration, are under-researched.

There is also significant scope for international collaboration as a means of addressing shared challenges (see e.g. Bibikas, Vorley and Wapshott, 2017; Heitor, 2015) and for engaging in productive debates around approaches rooted in different contexts and responding to different objectives. This broadening scope of collaborators may also involve new ways of thinking about the provision of entrepreneurship education, for example involving the 'enterprise industry' which includes a broad range of often profit-seeking businesses providing forms of support, advice and advocacy services to entrepreneurs and small businesses (Mallett, forthcoming). Such organisations and the networks that can develop between and around them offer further potential ways to root entrepreneurship 
education in practice as well as to develop network building and valuable learning communities (Zhang and Hamilton, 2010).

This introduction has sketched out some potential areas for collaboration and innovation in the various domains of entrepreneurship education and the entrepreneurial university. The remainder will introduce the articles included in the Special Issue. These articles gather together valuable insights into the variety of forms of collaboration that are of relevance to entrepreneurship education in a range of contexts. The authors provide different perspectives on the challenges facing entrepreneurship education and HEIs, different forms of collaboration and different opportunities for innovation that may arise as a result. The Special Issue includes international examples of such innovations in entrepreneurship education with a view to establishing fresh ideas and insights that may be of wider application within the education, entrepreneurship, $\mathrm{HEI}$ and policy communities.

\section{The articles in this Special Issue}

The first article in this Special Issue is 'Boundary crossing ahead: perspectives of entrepreneurship by sustainability educators in Higher Education' by Lynne Wyness and Paul Jones. Wyness and Jones adopt a communities of practice lens to explore collaborations across disciplines, in this case entrepreneurship and sustainability. In doing so, the study illuminates the delivery of entrepreneurship education outside the business school. In contrast to the urgency of the contribution and value entrepreneurship for organisation such as the OECD and amongst business and management students, amongst those delivering sustainability education, views were found to be more mixed. This has important implications for those who simply seek to copy and paste courses throughout the academic curriculum, highlighting the potential for powerful, problematic boundaries between the 
different communities of practice that might limit the extent of in-depth, productive collaboration. The authors also highlight the importance of ongoing learning across disciplines through collaborative practice.

The theme of collaboration in programme delivery is further developed in 'The use of MOOCs in Social Enterprise Education: An evaluation of a North-South collaborative FutureLearn Program' by Sara Calvo, Andres Morales and Jeremy Wade. The authors explore the possibilities of collaboration in the creation, development and implementation of massive open online courses (MOOCs), identifying MOOCs as offering the potential for new forms of international collaboration. Here, this is explored in terms of a collaboration between the Global North and Global South through the fascinating case study of a specific programme and its outcomes.

The third article in the Special Issue is 'Focus Point: the need for alternative insight into the entrepreneurial education paradigm' by David Higgins, Deema Refai and Diene Keita. This article focuses on the centrality of understanding the social practice of entrepreneurship for entrepreneurship education and the ways in which this requires pedagogical innovation. One way this can be achieved is through reframing our understanding of students as collaborators involved in the co-production of learning and knowledge creation. The authors argue that it is through collaborative forms of education that engage students in experiential learning that we can explore more deeply the implications of the student as 'entrepreneur'.

Outside the classroom, the possibilities of collaboration also identify the important linkages between universities and industry, for example in terms of knowledge transfer. 'Dynamic 
capabilities and the entrepreneurial university: a perspective on the knowledge transfer capabilities of universities' by Noel O'Reilly and Peter Robbins begins by tracing the evolution of the entrepreneurial university, a process that has necessitated a much wider agenda of engagement and collaboration with different stakeholders. Their article goes on to emphasise the importance of developing an innovative culture and those dynamic capabilities which support knowledge transfer, indicating the extent to which embracing a third mission for HEls has significant implications that continue to be explored and addressed.

The Special Issue concludes with a book review by Nuno Crespo that helps to highlight a further agenda in the evolution of universities' role in wider society and their positioning as entrepreneurial institutions. The book under review, Entrepreneurial Universities: Collaboration, Education and Policies by Ferreira, Fayolle, Ratten and Raposo, draws out collaboration primarily in terms of the development of policy. However, it is also keenly attuned to the importance of industry collaboration, including in specific entrepreneurship education programmes. It is thus another perspective on several of the themes productively explored by the Special Issue's contributors.

Together, the collection of articles comprising this Special Issue of the Journal of Small Business and Entrepreneurship suggests an exciting agenda for both research and pedagogical practice in the field of entrepreneurship education. The importance of collaboration is demonstrated by each of the articles, suggesting a variety of means by which we might continue to build towards an entrepreneurship education that is vibrant, innovative and impactful. Above all, these articles suggest the importance of ongoing 
development and learning within the field of entrepreneurship education and the ways this might be achieved through collaboration.

\section{References}

Bibikas, D., Vorley, T. and Wapshott, R. 2017. "Pan-European entrepreneurial summer academies with impact: the case of STARTIFY7." In Entrepreneurship Education: New Perspectives on Research, Policy and Practice edited by Jones, P., Maas, G. and Pittaway, L., pp. 261-281. London: Emerald.

Culkin, N. 2016. "Entrepreneurial universities in the region: the force awakens?" International Journal of Entrepreneurial Behavior \& Research, 22(1): 4-16. Doi: 10.1108/IJEBR-12-2015-0310

Duval-Couetil, N. 2013. "Assessing the impact of entrepreneurship education programs: Challenges and approaches." Journal of Small Business Management, 51(3): 394-409. Doi: $10.1111 /$ jsbm.12024

Etzkowitz, H. 2004. "The evolution of the entrepreneurial university." International Journal of Technology and Globalisation, 1(1): 64-77. Doi: 10.1177/0539018413485832

Fayolle, A. 2013. "Personal views on the future of entrepreneurship education." Entrepreneurship \& Regional Development, 25(7-8): 692-701. Doi: 10.1080/08985626.2013.821318

Fayolle, A., Verzat, C. and Wapshott, R. 2016. "In quest of legitimacy: The theoretical and methodological foundations of entrepreneurship education research." International Small Business Journal, 34(7): 895-904. Doi: 10.1177/0266242616649250

Ferreira, J., Fayolle, A., Ratten,V. and Raposo M. 2018. Entrepreneurial Universities: Collaboration, Education and Policies. Cheltenham (UK): Edward Elgar.

Janssen, F. and Bacq, S. 2010. "Cultural and outcomes-related issues in implementing an interdisciplinary cross-campus entrepreneurship education program." Journal of Small Business \& Entrepreneurship, 23(sup1): 733-746. Doi: 10.1080/08276331.2010.10593513

Jongbloed, B., Enders, J. and Salerno, C. 2008. "Higher education and its communities: Interconnections, interdependencies and a research agenda." Higher Education, 56(3): 303-324. Doi: 10.1007/s10734-008-9128-2

Katz, J.A. 2003. "The chronology and intellectual trajectory of American entrepreneurship education: 1876-1999." Journal of Business Venturing, 18(2): 283-300. Doi: 10.1016/S0883-9026(02)00098-8 
Kuratko, D.F. 2005. "The emergence of entrepreneurship education: Development, trends, and challenges." Entrepreneurship Theory and Practice, 29(5): 577-598. Doi: 10.1111/j.1540-6520.2005.00099.x

McCarver, D., Jessup, L. and Davis, D. 2010. "Building Entrepreneurship across the University: Cross-Campus Collaboration between Business and Engineering." Journal of Small Business \& Entrepreneurship, 23(sup1): 761-768. Doi: 10.1080/08276331.2010.10593515

Mallett, O. forthcoming. "Business Support as Regulatory Context: Exploring the Enterprise Industry." In Creating Entrepreneurial Space: Talking Through Multi Voices, Reflections On Emerging Debates Vol.2, edited by Higgins, D., Jones, P. and McGowan, P.. Bingley: Emerald.

Maas, G. and Jones, P. 2017. Entrepreneurship Centres: Global Perspectives on their Contributions to Higher Education Institutions. London: Palgrave

Menzies, T.V. 2000. "An Exploratory Study of University Entrepreneurship Centres in Canada: A First Step in Model Buildings." Journal of Small Business \& Entrepreneurship, 15(3): 15-38. Doi: 10.1080/08276331.2000.10593287

Neck, H.M. and Greene, P.G. 2011. "Entrepreneurship education: known worlds and new frontiers." Journal of Small Business Management, 49(1): 55-70. Doi: 10.1111/j.1540627X.2010.00314.x

Nicolosi, P. and Keeling, T. 2013. Anchor Institution Strategies for Colleges and Universities. Arizona: Hinshaw Consulting.

OECD 2018. Declaration on Strengthening SMEs and Entrepreneurship for Productivity and Inclusive Growth. Paris: OECD.

Philpott, K., Dooley, L., O'Reilly, C. and Lupton, G. 2011. "The entrepreneurial university: Examining the underlying academic tensions." Technovation, 31(4): 161-170. Doi: 10.1016/j.technovation.2010.12.003

Pugh, R., Hamilton, E., Jack, S. and Gibbons, A. 2016. “A step into the unknown: universities and the governance of regional economic development." European Planning Studies, 24(7): 1357-1373. Doi: 10.1080/09654313.2016.1173201

Solomon, G.T., Duffy, S. and Tarabishy, A. 2002. "The state of entrepreneurship education in the United States: A nationwide survey and analysis." International Journal of Entrepreneurship Education, 1(1): 65-86. Doi: 10.1108/14626000710746637

Zhang, J. and Hamilton, E. 2010. "Entrepreneurship education for owner-managers: the process of trust building for an effective learning community." Journal of Small Business \& Entrepreneurship, 23(2): 249-270. Doi: 10.1080/08276331.2010.10593485 